\title{
Utilization of plant resources among the Kankanaeys in Kibungan, Benguet Province, Philippines
}

\author{
ABIGAIL T. BERSAMIN ${ }^{1}$, JUDE L. TAYABEN ${ }^{2}$, KRYSSA D. BALANGCOD ${ }^{3}$, ASHLYN KIM D. BALANGCOD ${ }^{3}$, \\ AMELIA C. CENDANA ${ }^{3}$, ELIZABETH T. DOM-OGEN ${ }^{2}$, LANCE OLIVER C. LICNACHAN ${ }^{3}$, BRENILYN SIADTO $^{4}$, \\ FREDA M. WONG ${ }^{5,6}$, TEODORA D. BALANGCOD ${ }^{3, \varphi}$ \\ ${ }^{1}$ Pines City Colleges. Magsaysay Avenue, 2600 Baguio City, Philippines \\ ${ }^{2}$ Benguet State University. Km. 6, La Trinidad, Benguet, Philippines \\ ${ }^{3}$ University of the Philippines Baguio. Governor Pack Road, 2600 Baguio City, Philippines. `email: tdbalangcod@up.edu.ph \\ ${ }^{4}$ Local Government Unit of Kibungan. Kibungan, Benguet Province, Philippines \\ ${ }^{5}$ Saint Louis University. Bonifacio St., 2600 Baguio City, Philippines \\ ${ }^{6}$ Philippine Science High School, Cordillera Administrative Region Campus. Irisan, 2600 Baguio City, Philippines
}

Manuscript received: 25 September 2020. Revision accepted: 26 December 2020.

\begin{abstract}
Bersamin AT, Tayaben JL, Balangcod KD, Balangcod AKD, Cendana AC, Dom-Ogen ET, Licnachan LOC, Siadto B, Wong FM, Balangcod TD. 2021. Utilization of plant resources among the Kankanaeys in Kibungan, Benguet Province, Philippines. Biodiversitas 4: 362-372. The use of plant resources for human basic need dates back to ancient times. Plants have been man's recourse for natural healing, food, and for cultural practices. This study aimed to document the rich flora of Kibungan, Benguet, Philippines that the Kankanaey tribe utilizes. Interviews and focused group discussions were used to gather data and it was supplemented with ocular inspection of the locality. Results revealed that there were various uses of plants that could be categorized into medicinal, food, house construction, and others. The leaves of medicinal plants are more frequently used to treat wounds, diarrhea, cough, and skin inflammation. Decoctions for natural remedies include gipas (Sarcandra glabra), gawed (Piper betle), and kutsay (Allium odorum). Plant foods such as fruits, root crops, and vegetables are either cultivated or gathered from the forest. Specifically, plants collected from the wild included pinit (Rubus fraxinifolius), amti (Solanum nigrum), bayabas (Psidium guajava), gatgattang (Sonchus arvensis), galyang (Alocasia macrorrhizos), and pako (Diplazium esculentum), while kamote (Ipomea batatas) and corn (Zea mays) are cultivated. The pine tree (Pinus kesiya) is the main raw material for house construction. Interestingly, dengaw (Acorus calamus) is regarded as an amulet, which is believed to ward off evil spirits.
\end{abstract}

Keywords: Kankanaey, Kibungan, medicinal plants, plant resources, utilization, wild plants

\section{INTRODUCTION}

The use of plant resources for human basic can be traced back to ancient times. Plants have been a man's recourse for natural healing, food, construction, and cultural practices. Notably, wild sources of medicinal plants were used by man for centuries in traditional healing systems (Ullah et al. 2013) Through the years, this indigenous system of folk medicine is passed down from the older to the younger generations (Ugulu et al. 2009; Ahmad et al. 2014). Additionally, in local societies, traditional healers are recognized and are often part of the cultural and traditional practices. They also have significant influence on local health practices (WHO 1978; Cheikhyoussef et al. 2011). To date, the use of traditional medicine led to the increase of ethnobotanical and ethnopharmacological studies (Verpoorte 2005; Heinrich 2008). Presently, ethnomedicinal studies are essential for the discovery of new herbal remedies from indigenous and endemic plant species (Mahmood et al. 2012, 2013; Tantengco 2018).

With the increasing emergence of diseases, the documentation of the traditional medicinal plants for treatment of various ailments is significant because it provides information that can lead to the discovery of potential and perhaps more efficient plant-based drugs (Rahmatullah et al. 2011). Other than plants being used as medicine, plant resources have provided the basic needs of local communities. Additionally, plants are tapped as raw materials for construction, food, clothing, kitchen paraphernalia, and other uses. The accessibility of the natural resources by local communities has allowed them to develop innovative uses. However, it has been observed that the traditional knowledge is rapidly eroding due to a number of factors such as migration of indigenous people from rural to urban areas, industrialization, rapid loss of natural habitats, and changes in lifestyle. To prevent the loss of ethnobotanical knowledge, it is important to document this before it is irretrievably gone (Teklehaymanot and Giday 2007). Moreover, ethnobotanical studies play an important role to humanity as it can be a source of information for the development of drugs that provide treatment to emerging diseases (Abdallah 2016; Millat 2017; Salvaña and Arnibal 2019; Syahdar et al. 2019). Ethnobotanical studies can also preserve the indigenous plant-based knowledge of the local communities, and ultimately conserve global heritage (Pei 2001; Teklehaymanot and Giday 2007; Fongod et al. 2014; 
Yaseen 2015).

The Cordillera region is located in Northern Luzon, Philippines, and is the largest of three mountain ranges. It is endowed with a diversity of flora and fauna with a semitemperate climate, matched with a rich mix of cultures. The different cultural groups in the Cordillera are knotted with the surrounding environment henceforth have developed indigenous knowledge on plant use. They have used plants for the treatment of various ailments, yet most of these have not yet been scientifically or clinically proven for their efficacy. Drug discovery is currently a top priority in the region due to emerging diseases and the development of resistance of microorganisms to antibiotics (Tacconelli et al., 2017).

Emerging diseases continue to increase, while commercial drugs are becoming expensive which is no longer within the affordability of marginal communities. Additionally, the decline of food sources is an increasing problem as an effect of population growth and climate change. These problems can contribute to poverty. In the past decades, published research on the medicinal properties and nutritional value of indigenous wild plants in the region is limited (Balangcod and Balangcod 2011; Barcelo-Chua 2014). Thus, the discovery of new drugs and promotion of the use of neglected and underutilized indigenous plants are being encouraged.

In recent years, the Philippine government has recognized the importance of ethnobotanical knowledge and drug discovery such that government agencies are now supportive in funding interested groups, mostly researchers from the academe. Therefore, this study aims to document the various useful plants and the accompanying indigenous knowledge of the Kankanaey in Kibungan, Benguet Province, and Northern Philippines before this knowledge is lost. This study employed ethnobotanical surveys and focused group discussions specifically among the Kankanaeys in Kibungan, Benguet in gathering the important data. Conversely, even with a diversity of cultures with a rich diversity of traditional knowledge on plant uses in the Cordillera, only a few studies on this indigenous knowledge have been published. Thus, this research's result is an important contribution to the growing knowledge or information about plant utilization in the Cordillera and in the country.

\section{MATERIALS AND METHODS}

\section{The study area}

Benguet is one of the six provinces in the Cordillera Administrative Region, Northern Luzon, Philippines (Figure 1). It is nestled within towering mountain ranges with a semi-temperate climate. It is the home of the centuries-old mummies, a place of steep and high mountains and different kinds of forests. The natural resources, including flora and fauna, are diverse in the region. Additionally, there is also the presence of cultural diversity of several tribes, most have spent their entire life in the forests. Thus, these people have developed their ingenuities in harnessing the plant resources around them. Therefore, indigenous knowledge on plant utilization in the region is inherent in the local communities (Balangcod and Balangcod 2011).

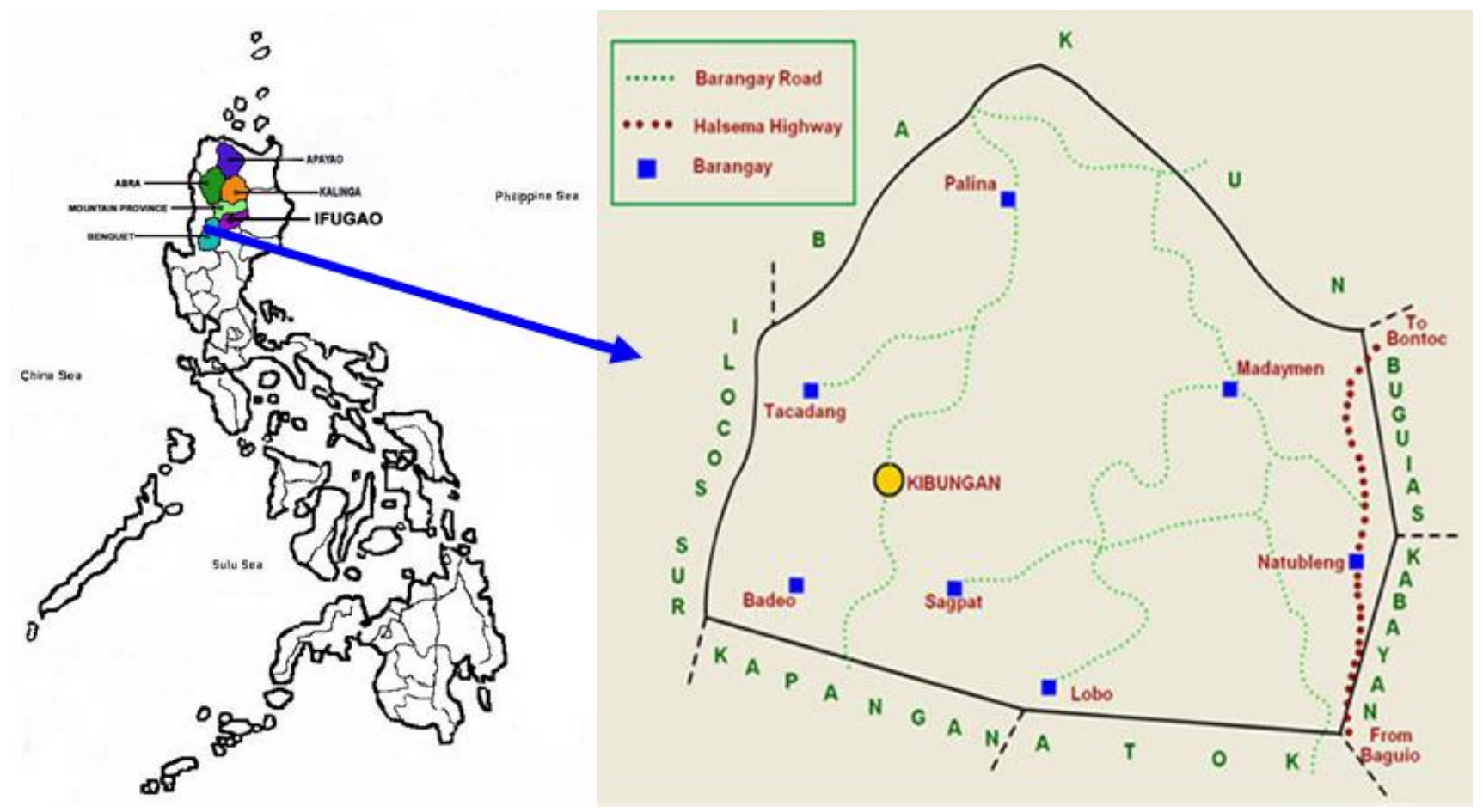

Figure 1. The location of the study area in Kibungan, Benguet Province, Philippines. Map of the Municipality of Kibungan, Benguet, Philippines was retrieved from https://benguet.gov.ph/v3/ 


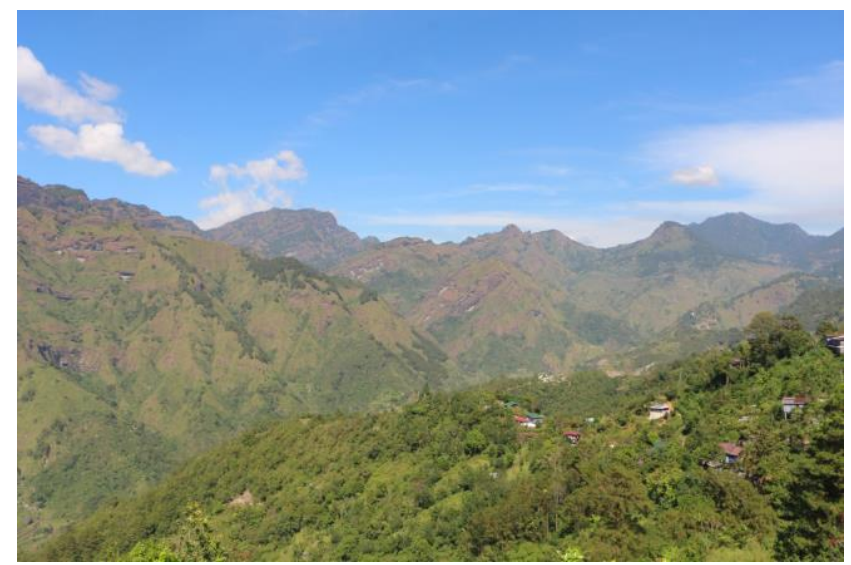

Figure 2. The villages in Kibungan, Philippines are situated within the forests hence the forest is the major source of their basic needs

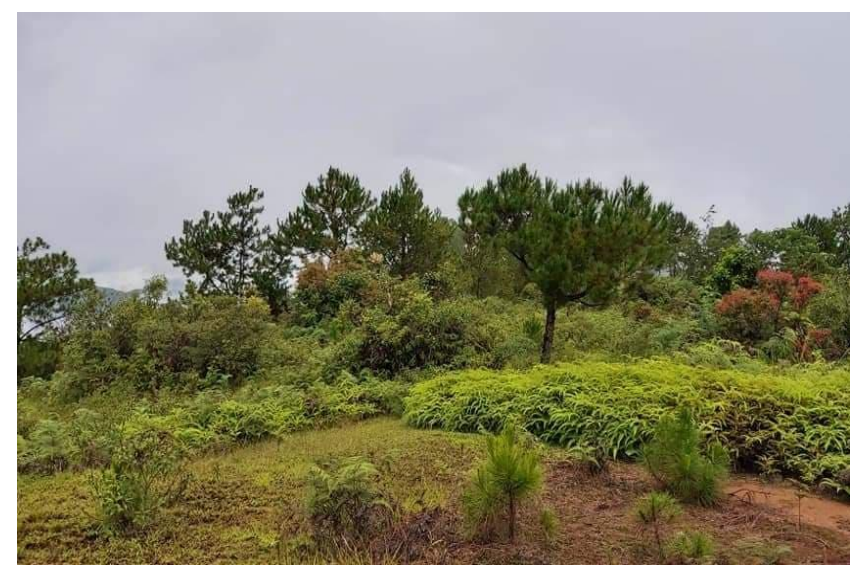

Figure 3. The forests in Kibungan, Philippines display a diverse vegetation

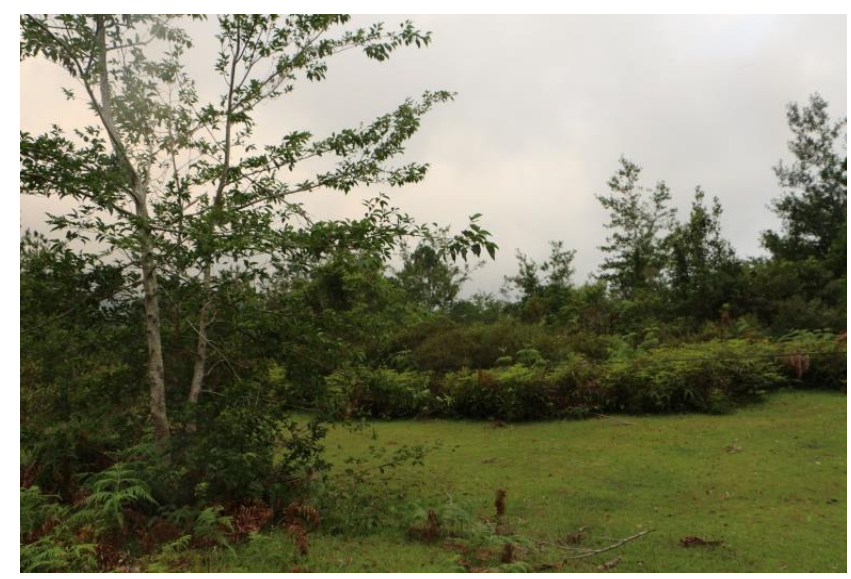

Figure 4. Some parts of the forest are used as foraging area for the cattle of the local communities in Kibungan, Philippines

Kibungan, where this study was specifically conducted, is one of the 13 municipalities of Benguet Province, Philippines. Kibungan (original name is Kibuñgan) is a fourth-class municipality, with geographical coordinates of $16^{\circ} 41^{\prime} 49^{\prime \prime}$ North and $120^{\circ} 39^{\prime} 34^{\prime \prime}$ East. The area is mountainous but rich in forest resources (Figures 2 to 4 ). It has eight barangays (Figure 1) and a population of approximately 17,292 (Philippine Statistics Agency, Population of Benguet 2015). Ninety percent of the population are Kankanaeys, the remaining $10 \%$ are a mix of other tribes and have stayed in the area as a result of intermarriage. The Kankanaeys of Kibungan are hardworking people, with agriculture as their major source of livelihood. They belong to a bigger tribe called the Igorots which means mountain people. The term Igorot generally refers to all the local communities living in the Cordillera region.

\section{Description of the participants}

The 47 participants in this study are mostly Kankanaeys, age range is from 20 to 70 , with an equal ratio of male and female. Most have stayed in the area for a minimum of 20 years. The predominant occupation is farming. The participants can be described as hardworking people, who almost spend their day time working in the rice fields and uma or swidden gardens. They dedicatedly tend their crops, from planting to harvest time, so that they can sell their harvests in order to buy the basic necessities like salt, sugar, and others. The people are humble and most of all, accommodating.

\section{Ethical considerations}

Permission from the mayor and prior informed consent from the community were sought before the conduct of the study. The local officials and elders were also present during the consultation. Information regarding ethnobotanical knowledge among the Kankanaeys was gathered through focused group discussions and interviews using a semi-structured questionnaire. Field observations confirmed the information gathered through interviews.

\section{Collection of data and plant samples}

Field visits involved direct contact with the community. An interview of 47 participants and two focused group discussions were conducted and supplemented with ocular inspection of the locality. Ethnobotanical surveys of the forest were accomplished with the help of some of the informants. A local resident who volunteered as a guide and knowledgeable about the uses of the plants and their distribution, was very helpful in data gathering. She accompanied us to the areas where we can collect some plant samples. Variables used to characterize and summarize the data were: local or common name, scientific name, family, parts of the plant used, ailments cured, how the plants were used, and citation frequency. The Use Value (UV) is an index that indicates relative importance of a species. This was computed for the medicinal plants following the formula, $\mathrm{UV}=\Sigma \mathrm{Ui} / \mathrm{n}$ where: $\mathrm{Ui}=$ the number of uses mentioned by each informant for a given species, $\mathrm{n}=$ the total number of informants (Zenderland et al. 2019). The Use Value is an index developed, that is applied in ethnobotany to calculate a value per folk or biological plant taxon. 


\section{RESULTS AND DISCUSSION}

Plant usage is an important part of human existence. The uses of plants can range from the most basic such as food, medicine, and clothing as well as other uses like construction of dwellings, animal houses, fences, ornaments, rituals, and others. The local communities in the Philippines, often times referred to as cultural minorities, have common and unique ways of plant utilization. This can be attributed to the type of vegetation that is present in their surroundings. It was observed that plants common in different places had common uses among the local groups. The plants that are unique in distribution has also unique uses for each group.

To the Kankanaey in Kibungan, there are various uses of plants that have been documented based on the interviews and focused group discussions. These are summarized separately according to their uses in Tables 1 to 4.

\section{Medicinal plants used by Kankanaeys in Kibungan, Benguet, Luzon, Philippines}

Twenty-eight plants were identified that has medicinal values and are being used by the informants. The leaves of medicinal plants are frequently used as decoction and poultice to treat wounds, diarrhea, cough, and skin inflammation. Among these natural remedies, gipas (Sarcandra glabra), gawed (Piper betle), and kutsay (Allium odorum) were noted as the common medicinal plants.

Of the 28 plants, four plants namely, bayabas (Psidium guajava), bawang (Allium sativum), laya (Zingiber officinale), and subusob (Blumea balsamifera) is included in the ten herbal plants identified by the Department of Health. It is interesting to note that twenty-eight plants are being used as herb or alternative medicine by the community for the treatment of ailments. The same plants were also reported by authors who made a study on the Kalanguya in Tinoc, Ifugao, Philippines and in Punjab Province, Pakistan (Balangcod and Balangcod 2011; Rehman 2017). The Department of Health had endorsed 10 herbal plants used by indigenous communities as cure for various ailments (Philippine Department of Health 2004).

From Table 1, it can be discerned that plants have various uses in the treatment of ailments. Wounds are the commonly treated conditions and the common diseases treated are cough and diarrhea. The plant part that is commonly used is the leaves. Interestingly, the Philippines' different local communities demonstrate similarities in the utilization of the plant resources around them. This finding is supported by a study that reported plant utilization among the Negritoes, Ibaloi, and Kalanguya (Fox 1952; Balangcod 2001; Balangcod and Balangcod 2011). This is perhaps because these societies have similar concepts of diseases.

\section{Plant parts used}

For the medicinal plants, it was observed that most preparations involved infusion or decoction of leaves. The stem and roots were used sparingly. For the food plants, the identified plants are mostly cropped hence are cultivated. Almost all plant parts are edible. Specifically, leaves are mostly gathered, cooked, and consumed. Fruits of cultivated plants like guava, beans (Phaseolus vulgaris), kape (Coffea arabica), papaya (Carica papaya), saba (Musa paradisiaca), sili (Capsicum frutescens), zucchini (Cucurbita pepo), sayote (Sechium edule) and others are eaten raw. Common wild fruits like pinit (Rubus fraxinifolius) and ul-ek (Saurauia elegans) are gathered from the forests. Seeds of corn are also cooked and eaten. Other plant parts such as rhizomes of gabi (Colocasia esculenta) and stem and shoots of camote (Ipomoea batatas) are also eaten after cooking. Construction materials for dwellings are sourced from the stem of woody plants and leaves of cogon (Imperata cylindrica). Brooms are made by bundling the stem and leaves of buybuy or tiger grass (Thysanolaena latifolia). The following tables demonstrate the different plants and the plant parts that are used.

\section{Mode of preparation}

For the mode of preparations for the medicinal plants in Table 1, it can be observed that this depends on the type of disease or ailment being treated. Usually for skin-related diseases, the common preparation is crushing the leaves and applying on the affected area as a poultice. For washing or use as an aseptic, this is done by decoction or boiling the leaves or other plant parts. Likewise, decoction is also used to treat cough and colds. For stomach related as well as kidney ailments, the common preparation is decoction of the leaves, stems, or barks and then drunk; some consume the plant part raw.

\section{Frequency and use value}

In table 1, most of the participants (frequency) revealed that gawed (Pierp betle) was the most known cure for fever (11), nine participants claimed that kutsay (Allium odorum) is used for the treatment of wounds and cough. Gipas (Sarcandra glabra), locally called mountain tea, is claimed by seven participants as cure for urinary tract infection (UTI), wounds, colds and as a source of antioxidants.

In recent years, the use of another indicator to denote the importance of a plant species for medicinal purposes is the use-value. Use value indicates the importance value of the plant, thus high scores indicate that the plant has higher importance value to the community. In Table 1, four plants namely; bayabas (Psidium guajava), dengaw (Acorus calamus), gipas (Sarcandra glabra) and laya (Zingiber officinale) have equal importance value of 0.085 , two plants namely; guyabano (Annona muricata) and sepal (Drimys piperata) have importance values of 0.064 . An importance value of 0.43 was reflected by five plants such as dengaw (Acorus calamus), paragis (Eleusine indica), pinit (Rubus fraxinifolius), putputod (Equisetum ramosissimum) and subusob (Blumea balsamifera). These plants with the top three high scores of use value demonstrate their importance to the local community in Kibungan. 
Table 1. Medicinal plants used by the Kankanaeys in Kibungan, Benguet, Luzon, Philippines

\begin{tabular}{|c|c|c|c|c|c|c|c|}
\hline $\begin{array}{l}\text { Local or common } \\
\text { name }\end{array}$ & Scientific name & Family & $\begin{array}{c}\text { Plant part } \\
\text { used }\end{array}$ & $\begin{array}{c}\text { How the plant } \\
\text { is used }\end{array}$ & $\begin{array}{c}\text { Ailments/ diseases } \\
\text { cured }\end{array}$ & $\begin{array}{c}\text { Citation } \\
\text { Freq. }\end{array}$ & $\begin{array}{c}\text { Use } \\
\text { value }\end{array}$ \\
\hline Atelba & Viburnum luzonicum Rolfe & Caprifoliaceae & Fruit & $\begin{array}{l}\text { Decoction of fruit is given during loose bowel } \\
\text { movement (LBM) }\end{array}$ & $\begin{array}{l}\text { Loose Bowel } \\
\text { Movement }\end{array}$ & 1 & 0.021 \\
\hline Avocado & Persea americana Mill. & Lauraceae & Leaves & $\begin{array}{l}\text { Decoction of leaves is given during diarrhea and to } \\
\text { relieve stomach pain }\end{array}$ & $\begin{array}{l}\text { Diarrhea, stomach } \\
\text { pain }\end{array}$ & 1 & 0.043 \\
\hline Bawang & Allium sativum $\mathrm{L}$. & Alliaceae & Bulb & Pounded and applied as poultice during toothache & Toothache & 1 & 0.021 \\
\hline Bayabas & Psidium guajava $\mathrm{L}$. & Myrtaceae & Shoots, fruit & $\begin{array}{l}\text { Crushed shoots are applied as poultice on wounds; } \\
\text { Decoction of shoots is used for allergies and rashes; } \\
\text { Fruit and shoot is eaten during diarrhea; }\end{array}$ & $\begin{array}{l}\text { Wounds, diarrhea, } \\
\text { Allergies, Rashes }\end{array}$ & 6 & 0.085 \\
\hline Biday & Ocimum tenuiflorum $\mathrm{L}$. & Lamiaceae & Root & Crushed roots are applied as poultice on wounds & Wounds & 1 & 0.021 \\
\hline Dungaw/dengaw & Acorus calamus $\mathrm{L}$. & Acoraceae & Roots, stem & $\begin{array}{l}\text { Crushed roots are applied as poultice on affected area to } \\
\text { relieve muscle pain, skin allergy and reduce } \\
\text { inflammation; Decoction of stem is given for dysentery }\end{array}$ & $\begin{array}{l}\text { Muscle pain, skin } \\
\text { inflammation or } \\
\text { allergy, dysentery }\end{array}$ & 3 & 0.085 \\
\hline $\begin{array}{l}\text { Eng-eng nga } \\
\text { (mushroom) }\end{array}$ & $\begin{array}{l}\text { Auricularia polytricha } \\
\text { (Mont.) Sacc. }\end{array}$ & Auriculariaceae & All parts & Eaten raw to expel worms (both humans and animals) & Expel worms & 1 & 0.021 \\
\hline Gawed & Piper betle $\mathrm{L}$. & Piperaceae & Leaves & $\begin{array}{l}\text { Leaves are applied directly on the forehead to abate } \\
\text { fever }\end{array}$ & Fever & 11 & 0.021 \\
\hline Gipas & $\begin{array}{l}\text { Sarcandra glabra (Thunb.) } \\
\text { Nakai }\end{array}$ & Chloranthaceae & Leaves, roots & $\begin{array}{l}\text { Decoction of leaves and roots is given during colds and } \\
\text { urinary tract infection (UTI); It is also used to wash } \\
\text { wounds; Leaves are also used as tea for cleansing }\end{array}$ & $\begin{array}{l}\text { UTI, wounds, colds; } \\
\text { anti-oxidant }\end{array}$ & 7 & 0.085 \\
\hline Guyabano & Annona muricata $\mathrm{L}$. & Annonaceae & Fruits, leaves & $\begin{array}{l}\text { Decoction of leaves is drunk as tea to treat cancer and } \\
\text { for cleansing }\end{array}$ & $\begin{array}{l}\text { Cancer, cleansing } \\
\text { (anti-oxidant) }\end{array}$ & 2 & 0.064 \\
\hline Kutsay & $\begin{array}{l}\text { Allium ramosum } \mathrm{L} . \\
\text { (Syn: Allium odorum } \mathrm{L} . \text { ) }\end{array}$ & Alliaceae & Leaves & $\begin{array}{l}\text { Crushed leaves are applied as poultice on wounds, } \\
\text { Decoction of leaves is given during cough }\end{array}$ & Wounds, cough & 9 & 0.043 \\
\hline Lagundi & Vitex negundo L. & Lamiaceae & leaves & Decoction of leaves is used during cough & Cough & 1 & 0.021 \\
\hline Lantana & Lantana camara $\mathrm{L}$. & Verbenaceae & Leaves & Decoction of leaves is given during cough & Cough & 1 & 0.021 \\
\hline Laya & Zingiber officinale Roscoe & Zingiberaceae & Rhizome & $\begin{array}{l}\text { Decoction from the pounded rhizome is given during } \\
\text { cough; can also be used as wash for wounds and after } \\
\text { giving birth, and poultice to relieve joint pain; Taken to } \\
\text { induce lactation }\end{array}$ & $\begin{array}{l}\text { Cough, wound, Joint } \\
\text { Pain, induce lactation }\end{array}$ & 6 & 0.085 \\
\hline Lemon grass & $\begin{array}{l}\text { Cymbopogon citratus (DC.) } \\
\text { Stapf }\end{array}$ & Poaceae & Leaves, roots & Boiled and taken as tea for cleansing & As anti-oxidant & 1 & 0.021 \\
\hline Madre de Cacao & $\begin{array}{l}\text { Gliricidia sepium (Jacq.) } \\
\text { Kunth ex Walp. }\end{array}$ & Fabaceae & Leaves & $\begin{array}{l}\text { Leaves are applied directly on the forehead to abate } \\
\text { fever }\end{array}$ & Fever & 1 & 0.021 \\
\hline
\end{tabular}




\begin{tabular}{|c|c|c|c|c|c|c|c|}
\hline Mahogany & $\begin{array}{l}\text { Swietenia mahagoni (L.) } \\
\text { Jacq. }\end{array}$ & Meliaceae & Seed & Eaten directly during diarrhea & Diarrhea & 1 & 0.021 \\
\hline Papait/bibiday & $\begin{array}{l}\text { Ageratina adenophora } \\
\text { (Spreng.) R.M.King \& } \\
\text { H.Rob. }\end{array}$ & Asteraceae & Leaves & Crushed leaves are applied as poultice on wounds & Wounds & 4 & 0.021 \\
\hline Paragis & Eleusine indica (L.) Gaertn. & Poaceae & $\begin{array}{l}\text { Leaves and } \\
\text { roots }\end{array}$ & $\begin{array}{l}\text { Decoction of leaves is given for cleansing/ } \\
\text { detoxification and treating dysmenorrhea }\end{array}$ & $\begin{array}{l}\text { Cleansing, } \\
\text { hypertension, } \\
\text { dysmenorrhea }\end{array}$ & 3 & 0.043 \\
\hline Pineapple & Ananas comosus (L.) Merr. & Bromeliaceae & Fruit peel & Boiled as tea for cleansing & As antioxidant & 1 & 0.021 \\
\hline Pinit & Rubus fraxinifolius Poir. & Rosaceae & Leaves, trunk & $\begin{array}{l}\text { Decoction of leaves and trunk is given during urinary } \\
\text { tract infection }\end{array}$ & $\begin{array}{l}\text { Urinary Tract } \\
\text { Infection }\end{array}$ & 1 & 0.043 \\
\hline Putputod (horsetail) & $\begin{array}{l}\text { Equisetum ramosissimum } \\
\text { Desf. }\end{array}$ & Equisetaceae & All parts & $\begin{array}{l}\text { Decoction of all parts is given during urinary tract } \\
\text { infection and kidney ailments }\end{array}$ & $\begin{array}{l}\text { Urinary Tract } \\
\text { Infection, kidney } \\
\text { ailments }\end{array}$ & 2 & 0.043 \\
\hline Sili & Capsicum frutescens $\mathrm{L}$. & Solanaceae & Seed & Gently rubbed on wounds & Wounds & 2 & 0.021 \\
\hline Sipal/sepal & Drimys piperita Hook.f. & Winteraceae & Fruit & $\begin{array}{l}\text { Dried and given during stomach ache; Eaten raw; } \\
\text { decoction of fruit is given during loose bowel movement } \\
\text { (LBM) }\end{array}$ & Stomach ache, LBM & 2 & 0.064 \\
\hline Subusob & Blumea balsamifera (L.) DC. & Asteraceae & Leaves, roots & $\begin{array}{l}\text { Decoction of leaves is given during cough. Roots are } \\
\text { boiled and the vapor is inhaled to treat colds. }\end{array}$ & Cough, Colds & 2 & 0.043 \\
\hline Tabako & Nicotiana tabacum $\mathrm{L}$. & Solanaceae & Leaves & Crushed leaves are applied as poultice on lump & Lump & 1 & 0.021 \\
\hline Tagumbaw & Jatropha curcas L. & Euphorbiaceae & Bark, leaves & $\begin{array}{l}\text { Crushed leaves and bark are applied as poultice on } \\
\text { fractures }\end{array}$ & Fracture & 3 & 0.021 \\
\hline Tinapong & Coffea arabica $\mathrm{L}$. & Rubiaceae & Fruit & Toasted and directly eaten during diarrhea & Diarrhea & 1 & 0.021 \\
\hline
\end{tabular}


Table 2. Plants used for food by the Kankanaeys in Kibungan, Benguet, Luzon, Philippines

\begin{tabular}{|c|c|c|c|c|c|c|}
\hline $\begin{array}{l}\text { Local or common } \\
\text { name }\end{array}$ & Scientific name & Family & $\begin{array}{c}\text { Plant part } \\
\text { used }\end{array}$ & How the plant is used & $\begin{array}{l}\text { Cultivated or taken from the } \\
\text { wild }\end{array}$ & $\begin{array}{l}\text { Citation } \\
\text { freq. }\end{array}$ \\
\hline Amti (weeds) & Solanum nigrum L. & Solanaceae & Leaves & Cooked, mixed with other foods & Forest & 2 \\
\hline Ayusep & Vaccinium myrtoides Miq. & Ericaceae & Fruit & Eaten raw & Wild & 2 \\
\hline Bayabas & Psidium guajava $\mathrm{L}$. & Myrtaceae & Shoots, Fruit & Cooked or eaten raw & Cultivated or wild & 9 \\
\hline Bilis & Garcinia vidalii Merr. & Clusiaceae & - & Eaten raw & Wild & 1 \\
\hline Binnok & Medinilla sp. & Melastomataceae & Leaves, fruit & Eaten raw & Wild & 2 \\
\hline Camote & Ipomoea batatas (L.) Lam. & Convolvulaceae & Root & Cooked and mixed with other food & Cultivated or wild & 6 \\
\hline Cassava & Manihot esculenta Crantz. & Euphorbiaceae & Tuber & Cooked & Wild & 2 \\
\hline Climbing Beans & Phaseolus vulgaris L. & Fabaceae & Fruit & Cooked & Wild & 1 \\
\hline Corn & Zea mays L. & Poaceae & Kernel, & Cooked & Cultivated or wild & 11 \\
\hline Gabi & Colocasia esculenta (L.) Schott & Araceae & Leaves, root & Cooked & Cultivated or wild & 9 \\
\hline Gaddang & Languas haenkei (C.Presl) Merr. & Zingiberaceae & Fruit & Eaten raw & Cultivated or wild & 1 \\
\hline Gagattang (Weeds) & Taraxacum officinale F.H.Wigg. & Asteraceae & Leaves & Cooked, mixed with other foods & Wild & 7 \\
\hline Galyang & Alocasia macrorrhizos (L.) G.Don. & Araceae & Corm, leaves & Cooked & Cultivated & 8 \\
\hline Kape & Coffea arabica $\mathrm{L}$. & Rubiaceae & Bean & Brewed and drank & Cultivated or wild & 8 \\
\hline Kendoy/Kendey & Rorippa indica $($ L.) Hiern. & Brassicaceae & Leaves & Cooked & Taken from the wild & 3 \\
\hline Laya & Zingiber officinale Roscoe & Zingiberaceae & Rhizome & Cooked, mixed with other foods & Wild, cultivated & 9 \\
\hline Pako & Diplazium esculentum (Retz.) Sw. & Athyrioideae & Leaves, Stem & Cooked & Cultivated or wild & 9 \\
\hline Papaya & Carica papaya $\mathrm{L}$. & Caricaceae & Fruit & Eaten raw & Cultivated or wild & 1 \\
\hline Pinet, Pinit & Rubus sp. & Rosaceae & Berries, fruit & Eaten raw & Wild & 3 \\
\hline Pomelo & Citrus maxima (Burm.) Merr. & Rutaceae & Fruit & Eaten raw & Cultivated or wild & 1 \\
\hline Pising & Colocasia esculenta (L.) Schott & Araceae & Corm, leaves & Cooked & Cultivated & 1 \\
\hline Saba & Musa $\times$ paradisiaca $\mathrm{L}$ & Musaceae & Fruit & Eaten raw or cooked & Cultivated & 2 \\
\hline Sayote & Sechium edule Sw. & Cucurbitaceae & Fruit & Cooked and mixed with other food & Taken from the wild & 2 \\
\hline Sili (Labuyo) & Capsicum frutescens $\mathrm{L}$. & Solanaceae & Fruit & Condiment & Cultivated & 1 \\
\hline Suyok(Rono), bellang & Miscanthus sinensis Anders. & Poaceae & Shoots & Eaten raw & Wild & 1 \\
\hline Ul-ek. Utok & Saurauia elegans Fern.-Vill. & Saururaceae & Fruit & Eaten raw & Wild & 1 \\
\hline Zucchini & Cucurbita pepo $\mathrm{L}$. & Cucurbitaceae & Flower & Cooked and mixed with other food & Cultivated & 1 \\
\hline
\end{tabular}


Table 3. Plants used for construction, carving, broom making and firewood by Kankanaeys in Kibungan, Benguet, Luzon, Philippines

\begin{tabular}{|c|c|c|c|c|c|c|}
\hline $\begin{array}{c}\text { Local or common } \\
\text { name }\end{array}$ & Scientific name & Family & $\begin{array}{c}\text { Plant part } \\
\text { used }\end{array}$ & How the plant is/ are used & Where gathered & $\begin{array}{l}\text { Citation } \\
\text { freq. }\end{array}$ \\
\hline Alnus & Alnus japonica (Thunb.) Steud. & Betulaceae & Trunk & Posts, walls, firewood & Forest & 6 \\
\hline Apiit/Apiitan & Clethra canescens var. luzonica (Merr.) Sleumer & Clethraceae & Trunk, stem & Animal house, hedges/fence & Forest & 1 \\
\hline Atelba & Viburnum luzonicum Rolfe & Caprifoliaceae & Stem & Hedges & Forest & 1 \\
\hline Bayabas & Psidium guajava $\mathrm{L}$. & Myrtaceae & Stem & Fences, stakes & Forest & 1 \\
\hline Buybuy & Thysanolaena latifolia (Roxb. ex Hornem.) Honda & Poaceae & Leaves, stem & Bundled to make brooms & Forest and cultivated & 7 \\
\hline Cogon & Imperata cylindrica (L.) P.Beauv. & Poaceae & Leaves & Used as roofing material & Forest & 8 \\
\hline Eucalyptus & Eucalyptus globulus Labill. & Myrtaceae & Trunk, stem & Posts, flooring, walls & Forest and cultivated & 1 \\
\hline Kawayan/Bamboo & Bambusa vulgaris Schrad. ex J.C.Wendl. & Poaceae & Stem & Hedges & Forest & 1 \\
\hline Manga & Mangifera indica $\mathrm{L}$. & Anacardiaceae & Trunk & Furniture, posts & Cultivated & 7 \\
\hline Narra & Pterocarpus indicus Willd. & Fabaceae & Stem, trunk & Furniture & Forest, cultivated & 9 \\
\hline Palayon/Palleyen & Lithocarpus jordanae (Laguna) Rehder & Fagaceae & Trunk & Posts, flooring, walls, poles & Forest & 1 \\
\hline Pa-o (Rono) & Miscanthus sinensis Andersson & Poaceae & Stem & Hedges & Forest & 1 \\
\hline Sabbang & Ficus sp. & Moraceae & Stem, trunk & Flooring & Cultivated & 1 \\
\hline Saleng/Pine tree & Pinus kesiya Royle ex Gordon & Pinaceae & Stem, trunk & Posts, flooring, walls, firewood & Forest, cultivated & 10 \\
\hline Tuel & Bischofia javanica Blume & Euphorbiaceae & Trunk & Pof flooring, walls & Forest & 1 \\
\hline
\end{tabular}




\section{Plants used for food by the Kankanaeys in Kibungan, Benguet, Luzon, Philippines}

The forest of Kibungan is abundant with edible plants, which the community enjoys like fruits, root crops, and vegetables. The pinit (Rubus fraxinifolius), amti (Solanum nigrum), bayabas (Psidium guajava), gatgattang (Sonchus arvensis), galyang (Alocasia macrorrhizos), kamote (Ipomea batatas) and pako (Diplazium esculentum) are among the wildly growing food resources. Table 2 presents the plants used for food by the Kankanaeys in Kibungan, Benguet. Most of the cultivated edible plants are common in other parts of the country also. It is because these are considered cash crops.

The vegetables are usually gathered, cooked, and consumed. Some are stored for other days like rice, corn, gabi, and camote. The latter two crops are sometimes reserved and served during festivities called cañaos, for the entire community to enjoy. Cañao refers to social gatherings among local communities in the Cordillera and is usually characterized by butchering of animals, local dances with gongs' accompaniment, striking of metals and amusements. Meat and vegetables are served to the attending participants and guests, invited or not invited, during a cañao. Usually, the merriment is spiced by serving rice wine called tapuy that is made from special variety of rice. This wine can raise the spirits and energy of the attendees. The local residents in Kibungan usually share their agricultural produce with their neighbors; some are sold to their marketplace from which the money is used to buy other kitchen needs like salt, sugar, bread and others.

\section{Plants used for construction, carving, broom making, firewood and other uses by the Kankanaeys in Kibungan, Benguet, Luzon, Philippines}

From the adjoining forests in Kibungan, trees are also gathered for their woody trunks to be used in making houses. The wood is used to build posts, walls, floors, and ceiling joists. The cogon, Imperata cylindrica, is utilized as roofing materials. For some plants, the stems and branches are used to build fences around the dwellings to keep stray animals from the immediate vicinity of the household. The buybuy (tiger grass), Thysanolaena latifolia is bundled to make brooms. The trunks of manga (Mangifera indica), and narra (Pterocarpus indicus), are utilized for furniture. Table 3 presents the plants used for these purposes.

\section{Plants used for ornaments/adornment, preservation of the dead, and rituals by Kankanaeys in Kibungan, Benguet, Luzon, Philippines}

The everyday life and cultural aspect of the local community in Kibungan can be reflected by the way they use some plants (Table 4). The dengaw (Acorus calamus) is used as an amulet, which is believed to ward off evil spirits. A piece of the root can also be pinned on clothes especially when travelling far distances from the village as a protection from being harmed by bad spirits that may be encountered along the way. Interestingly, it can be noted that bayabas (Psidium guajava) and niyog (Cocos nucifera) are used to preserve the dead as substitutes to formalin as embalming agent. The women are also vain as demonstrated by the use of seeds of takkayan (Coix lacryma-jobi) for ornaments. Specifically, the women gather the seeds of the said plant and craft these into earrings, bracelets and necklaces. Curtains, bags and similar items can be seen from the beads of takkayan. In some places in the Philippines, the seeds can also be crafted into rosaries. In Kibungan, Benguet, the takkayan grows wild in rice paddies, riverbanks and marginal areas.

Notably, the different families of plants utilized as food in Kibungan are Solanaceae, Rubiaceae, Brassicaceae, Zingiberaceae, Rosaceae, Rutaceae, Poaceae, Cucurbitaceae, Saururaceae, Caricaceae and Athyrioideae. The flora of Kibungan is of diverse plant families that are wild while others can be cultivated. The Kankanaeys are known as vegetable growers or farmers and as such, they also cultivate some plants that grow well on the farm such as bayabas (Psidium guajava), corn (Zea mays), gabi (Colocasia esculenta), galyang (Alocasia macrorrhiza), camote (Ipomea batatas), kape (Coffea arabica), laya (Zingiber officinale) and others as shown in Table 2. The plant parts that are mostly utilized for food are the fruits and the leaves. The fruits and the leaves are either cooked or eaten raw.

In Kibungan, Benguet, the plants which are utilized in construction belong to different plant families such as Betulaceae, Pinaceae, Clethraceae, Caprifoliaceae, Myrtaceae, Poaceae, Anacardiaceae, Fabaceae, Fagaceae, Moraceae, and Euphorbiaceae. The trunks are utilized for posts, walls, flooring, and hedges. They are also used as firewood. Most of these are growing in the forest. It can be noted that these plants are highly beneficial as they are the source of materials for house construction.

Table 4. Plants used for ornaments/adornment, rituals/ mummification by Kankanaeys in Kibungan, Benguet, Luzon, Philippines

\begin{tabular}{|c|c|c|c|c|c|c|}
\hline $\begin{array}{l}\text { Local or common } \\
\text { name }\end{array}$ & Scientific name & Family & $\begin{array}{l}\text { Plant part } \\
\text { used }\end{array}$ & How the plant is used & $\begin{array}{l}\text { Where } \\
\text { gathered }\end{array}$ & $\begin{array}{l}\text { Citation } \\
\text { freq. }\end{array}$ \\
\hline Bayabas & Psidium guajava $\mathrm{L}$. & Myrtaceae & Leaves, shoots & $\begin{array}{l}\text { Mummification, } \\
\text { Decoction is used to wash the corpse } \\
\text { and as substitute for formalin }\end{array}$ & $\begin{array}{l}\text { Wild or } \\
\text { cultivated }\end{array}$ & 9 \\
\hline Dungaw/dengaw & Acorus calamus L. & Acoraceae & Roots & $\begin{array}{l}\text { Amulet, attached to clothing to drive } \\
\text { away evil spirits }\end{array}$ & Cultivated & 14 \\
\hline Niyog & Cocos nucifera $\mathrm{L}$. & Arecaceae & Fruit & $\begin{array}{l}\text { The extracted oil is rubbed on the } \\
\text { body for the preservation of the dead }\end{array}$ & $\begin{array}{l}\text { Forest, } \\
\text { cultivated }\end{array}$ & 12 \\
\hline Takkayan/tukkayan & Coix lacryma-jobi L. & Poaceae & Fruit & $\begin{array}{l}\text { Necklace, bracelet, earring, curtains, } \\
\text { bag, Christmas tree, basket }\end{array}$ & $\begin{array}{l}\text { Riverbank, } \\
\text { field }\end{array}$ & 11 \\
\hline Rice & Oryza sativa $\mathrm{L}$. & Poaceae & Grain & Prayer, drink (tapuy) & Cultivated & 1 \\
\hline
\end{tabular}


In almost all local communities in the Cordillera, including Kibungan, traditional knowledge on plant use and other natural resources is closely tied with the world of spirits. In each village, it is believed that certain diseases are caused by supernatural beings (Balangcod and Balangcod 2018; Balangcod 2018). Hence, illnesses that cannot be cured or treated by plants and modern medicine, can be treated through the meddling of a priest or mambunong, whose role is of prime importance in the village. The village priest usually performs rituals and offerings, in the forms of plants, clothing, and the like, to appease the spirits who are believed to have caused the illnesses.

In general, the close association of the Kankanaey with their environment, the development of traditional uses of plants and other resources around them, and their awareness of the importance of the useful plants are commendable. This is revealed in the informal interviews, focused group discussions, and site observations. Additionally, while there are some unique uses of plants among the Kankanaey in Kibungan, there also exists a pattern of utilization of plant-based medicines relative to other local communities in the Philippines.

In conclusion, several plants were reported to be used for various purposes such as medicinal, food, house construction and for other purposes. It has been noted that wild plants, which are highly beneficial, are naturally found in Kibungan, Benguet. The traditional uses of plants, not only as medicine but also for other purposes like food, construction and many others are still practiced in Kibungan, Benguet even at present. For future studies, the vast richness of plant indigenous knowledge can be augmented by determining the bioactive components of the medicinal plants and performing bioassays. Additionally, if not managed properly, the continuous gathering of plant resources can lead to their depletion. Therefore, the protection of the environment to conserve the natural habitats of the plants can be promoted. Initiatives for their cultivation can be advocated.

\section{ACKNOWLEDGEMENTS}

The authors are grateful to the Commission on Higher Education DARETO for financial assistance. We are equally thankful to the local communities and participants who unselfishly shared the information. The authors are also grateful to the local government officials for allowing us to conduct the study and to the University of the Philippines Baguio as the lead implementing institution for this project.

\section{REFERENCES}

Abdallah EM. 2016. Medicinal plants with antibacterial properties against Helicobacter pylori: A Brief Review. J Nutraceuticals Food Sci 1: 3

Ahmad M, Sultana S, Fazli-Hadi S, Hadd T, Rashid S, Zafar M, Khan MA, Khan MP Z, Yaseen G. 2014. An ethnobotanical study of medicinal plants in high mountainous region of Chail valley (District Swat-Pakistan). J Ethnobiol Ethnomed $10: 1-18$.

Balangcod TD, Balangcod AKD. 2011. Ethnomedical knowledge of plants and healthcare practices among the Kalanguya tribe in Tinoc, Ifugao, Luzon, Philippines, Indian J Tradit Knowl 10 (2): 227-238.

Balangcod TD, Balangcod KD. 2018. Plants and Culture: plant utilization among the local communities in Kabayan, Benguet Province, Philippines. Indian J Tradit Knowl 17 (4): 609-622.

Balangcod TD. 2001. The useful flora of Tabaan Norte, Tuba, Benguet Province, In: Towards Understanding Peoples of the Cordillera: A Review of Research on History, Governance, Resources, Institutions and Living Traditions. Cordillera Studies Center, UP Baguio, Philippines.

Balangcod TD. 2018. A glimpse of the fire mummies of Kabayan, Benguet, Luzon, Philippines and the role of plants associated with the mummification process. Indian J Tradit Knowl 17 (2): 307-313.

Barcelo-Chua RT. 2014. Ethno-botanical survey of edible wild fruits in Benguet, Cordillera administrative region, the Philippines, Asian Pac J Trop Biomed 4 (Suppl 1): S525-S538.

Cheikhyoussef A, Shapi M, Matengu K, Ashekele HM. 2011. Ethnobotanical study of indigenous knowledge on medicinal plant use by traditional healers in Oshikoto region, Namibia. J Ethnobiol Ethnomed 7: 1-11.

Department of Health. 2004. Philippine Pharmacopeia 1. Department of Health, Bureau of Food and Drugs, Manila.

Fongod A, Genla N, Ngoh ML, Veranso-Libalah MC. 2014. Ethnobotany, indigenous knowledge and unconscious preservation of the environment: an evaluation of indigenous knowledge in South and Southwest Regions of Cameroon. Int J Biodivers Conserv 6 (1): 85 99. DOI: $10.5897 /$ IJBC.2013.0637

Fox RB. 1952. The Pinatubo Negritoes: their useful plants and material culture, Philippine. J Sci 81: 173-391.

Heinrich M. 2008. Ethnopharmacy and natural product research Multidisciplinary opportunities for research in the metabolomic age. Phytochem Lett 1: 1-5.

Mahmood A, Mahmood A, Malik RN, Shinwari ZK. 2013. Indigenous knowledge of medicinal plants from Gujranwala district, Pakistan. J Ethnopharmacol 148: 714-723.

Mahmood A, Mahmood A, Malik RN. 2012. Indigenous knowledge of medicinal plants from Leepavalley, Azad Jammu and Kashmir, Pakistan. J Ethnopharmacol 143: 338-346.

Millat MS, Islam S, Hussain MS, Moghal MMR, Islam T. 2017. Antibacterial profiling of Launaea sarmentosa (Willd.) and Bruguiera cylindrica (L.): Two distinct ethno medicinal plants of Bangladesh. Eur Exp Biol 7: 6

Pei SJ. 2001. Ethnobotanical approaches of traditional medicine studies: some experiences. Asia Pharm Biol 39: 74-79.

Philippine Statistics Agency. 2015. Population of Benguet. https://benguet.gov.ph/v3/wp-content/uploads/2018/11/demographics.pdf.

Rahmatullah M, Azam MNK, Rahman MM, Seraj S, Mahal MJ, Mou SM, Chowdhury MH. 2011. A survey of medicinal plants used by Garo and non-Garo traditional medicinal practitioners in two villages of Tangail district, Bangladesh. Am Eur J Sustain Agric 5: 350-357.

Rehman MN, Ahmad M, Sultana S, Zafar M, Edwards S. 2017. Relative popularity level of medicinal plants in Talagang, Punjab Province, Pakistan. Braz J Pharmacog 27: 751- 775.

Salvaña FR, Arnibal SL. 2019. Importance of indigenous communities' knowledge and perception in achieving conservation: a case study from Manobo tribe of Southern Mindanao, Philippines. Asian J Ethnobiol 2 (2): 54-61.

Syahdar SA, Tamalene MN, Hasan S. 2019. Bakera: tradition of medicinal plants utilization for therapy, prevention and recovery of diseases in Jailolo Sultanate custome society, Indonesia. Asian J Ethnobiol 2 (2): 41-47.

Tacconelli E., Carrara E., Savoldi A., et al. 2017. Discovery, research, and development of new antibiotics: The WHO priority list of antibioticresistant bacteria and tuberculosis. The Lancet Infectious Diseases. 18: 3. DOI: 10.1016/S1473-3099(17)30753-3

Tantengco OAG, Condes MLC, Estadilla HHT, Ragragio EM, Condes, HHT, Estadilla EMR. 2018. Ethnobotanical survey of medicinal plants used by Ayta Communities in Dinalupihan, Bataan, Philippines. Pharmacog J 10 (5): 859-870. 
Teklehaymanot T, Giday M. 2007. Ethnobotanical study of medicinal plants used by people in Zegie Peninsula, Northwestern Ethiopia. J Ethnobiol Ethnomed 3: 1-11.

Ugulu I, Baslar S, Yorek N, Dogan Y. 2009. The investigation and quantitative ethnobotanical evaluation of medicinal plants used around Izmir Province, Turkey. J Med Plant Res 3: 345-367.

Ullah M, Khan MU, Mahmood A, Naseem R, Hussain M, Wazir SM, Doud M, Shinwari ZK. 2013. An ethnobotanical survey of indigenous medicinal plants in Wana District, South Waziristan Agency. Pak J Ethnopharmacol 150: 918-924.

Verpoorte R, Choi Y, Kim H. 2005. Ethnopharmacology and systems biology: a perfect holistic match. J Ethnopharmacol 100: 53-56.
WHO. 1978. The Promotion and Development of Traditional Medicine. Report of a World Health Organization Meeting, Technical Report Series 622. World Health Organization, Geneva.[

Yaseen G, Ahmad M, Sultana S, AlharrasiAS, Hussain J, Zafar M, UrRehman S. 2015. Ethnobotany of medicinal plants in the Thar Desert (Sindh) of Pakistan. J Ethnopharmacol 163: 43-59.

Zenderland J, Hart R, Bussmann RW, Zambrana NYP, Sikharulidze S, Kikvidze Z, Kikodze D, Tchelidze D, Khutsushvili M, Batsatsashvili K. 2019. The use of "use value": Quantifying importance in ethnobotany. Econ Bot 73: 293-303. DOI: 10.1007/s12231-01909480-1. 